\title{
Patent Trolls: Evidence from Targeted Firms
}

\section{Citation}

Cohen, Lauren, Umit G. Gurun, and Scott Duke Kominers. "Patent Trolls: Evidence from Targeted Firms." Harvard Business School Working Paper, No. 15-002, July 2014. (Revised August 2014.)

\section{Permanent link}

http://nrs.harvard.edu/urn-3:HUL.InstRepos:13350439

\section{Terms of Use}

This article was downloaded from Harvard University's DASH repository, and is made available under the terms and conditions applicable to Open Access Policy Articles, as set forth at http:// nrs.harvard.edu/urn-3:HUL.InstRepos:dash.current.terms-of-use\#OAP

\section{Share Your Story}

The Harvard community has made this article openly available.

Please share how this access benefits you. Submit a story.

Accessibility 
H A R VAR D

\section{Patent Trolls: Evidence from Targeted Firms \\ Lauren Cohen \\ Umit G. Gurun \\ Scott Duke Kominers}

\section{Working Paper}

15-002

August 7, 2014 


\title{
Patent Trolls: Evidence from Targeted Firms*
}

\author{
Lauren Cohen \\ Harvard Business School and NBER
}

Umit G. Gurun

University of Texas at Dallas

Scott Duke Kominers

Harvard University

First Version: March 10, 2014

This Version: August 7, 2014

${ }^{*}$ The authors thank Jim Bessen, Wesley Cohen, Drew Fudenberg, Albert Galasso, Bernhard Ganglmair, Joshua Gans, Daniel Gottlieb, Stuart Graham, Paul Po-Hsuan Hsu, Bob Hunt, Julian Kolev, Josh Lerner, Chris Malloy, Adair Morse, Jillian Popadak, Assaf Romm, Fiona Scott-Morton, Amit Seru, Scott Stern, Balazs Szentes, Catherine Tucker, Martin Watzinger, and seminar participants at Bentley, Brandeis, HKU, HKUST, Nanyang Technological University, NBER, Ozyegin University, and TCU for comments. We are grateful to Daniel McCurdy, Christopher Reohr, and Shashank Tiwari at PatentFreedom for graciously providing data used in this study. The authors gratefully acknowledge funding from the National Science Foundation (grants SES-0847395 and CCF-1216095). Kominers also gratefully acknowledges the hospitality of Microsoft Research New England and the support of the Harvard Milton Fund. 


\title{
Patent Trolls: Evidence from Targeted Firms
}

\begin{abstract}
We provide theoretical and empirical evidence on the evolution and impact of non-practicing entities (NPEs) in the intellectual property space. Heterogeneity in innovation, given a cost of commercialization, results in NPEs that choose to act as "patent trolls" that chase operating firms' innovations even if those innovations are not clearly infringing on the NPEs' patents. We support these predictions using a novel, large dataset of patents targeted by NPEs. We show that NPEs on average target firms that are flush with cash (or have just had large positive cash shocks). Furthermore, NPEs target firm profits arising from exogenous cash shocks unrelated to the allegedly infringing patents. We next show that NPEs target firms irrespective of the closeness of those firms' patents to the NPEs', and that NPEs typically target firms that are busy with other (non-IP related) lawsuits or are likely to settle. Lastly, we show that NPE litigation has a negative real impact on the future innovative activity of targeted firms.
\end{abstract}

JEL Classification: D2, K1, O31.

Keywords: Patent trolls, NPEs, Innovation, Patents. 
Clearly defined property rights are essential for well-functioning markets. In the case of intellectual property (IP), however, property rights are complex to define; unlike ownership of physical assets, the space of ideas is difficult to clearly delineate. A solution employed by the United States and many other countries is the patent - a property right allowing an idea's owner sole commercialization rights for a period of time. A patent holder can therefore block commercialization of inventions arguably similar to the patented invention. In the United States, the legal system is the arbiter of patent infringement; thus, legal action (or the threat of legal action) is the main lever by which patent holders challenge alleged intellectual property infringers.

A new organizational form, the non-practicing entity (hereafter, NPE), has recently emerged as a major driver of IP litigation. NPEs amass patents not for the sake of producing commercial products, but in order to prosecute infringement on their patent portfolios. The rise of NPEs has sparked a debate regarding their value and their impact on innovation. Proponents argue that imperfections in the legal system implicitly reward large, well-funded organizations, enabling them to infringe at will on small innovators' IP and that NPEs are there to protect small innovators from such abuse. Opponents cast NPEs as organizations that simply raise the costs of innovation by exploiting the fact that an imperfect legal system will rule in their favor sufficiently often - even if no infringement has actually occurred - that the credible threat of the legal process can yield rents from producing, innovative firms. ${ }^{1}$ Reflecting this debate, there have been (as of today) at least ten bills introduced in Congress proposing to regulate the licensing of patents to NPEs. ${ }^{2}$

We inform the ongoing debate on NPEs by providing the first large-sample evidence on precisely which corporations NPEs target in litigation, when NPE litigation occurs, and

\footnotetext{
${ }^{1}$ Bessen et al. (2011) estimate that from 2007 to 2010, these litigation (and settlement) losses averaged over $\$ 83$ billion per year in 2010 dollars (just summing over the losses to publicly traded firms). This is equivalent to over $25 \%$ of annual United States industrial R\&D investment.

${ }^{2}$ In the last four years, Congress has considered the Innovation Act (H.R. 3309), the Patent Transparency and Improvements Act (S. 1720), the Patent Quality Improvement Act (S. 866), the Patent Abuse Reduction Act (S. 1013), the Patent Litigation Integrity Act (S. 1612), the Innovation Protection Act (H.R. 3309), the Patent Litigation and Innovation Act (H.R. 2639), the SHIELD Act (H.R. 845), the Stopping the Offensive Use of Patents Act (STOP Act) (H.R. 2766), and the End Anonymous Patents Act (H.R. 2024).
} 
the impact of NPE litigation on the targeted firms' innovative activity. We first develop a parsimonious model of an innovative economy in which NPEs endogenously arise as patent trolls - agents that sue opportunistically in hopes that an imperfect legal system will rule in their favor, maximizing expected proceeds rather than maximizing penalties to infringement behavior. We assume heterogeneity in innovation quality across agents. This heterogeneity, together with a cost of commercialization and a litigation mechanism that imperfectly enforces infringement, leads some patent holders to endogenously decide to litigate commercializing firms instead of commercializing their own inventions. This decision depends on a comparison of the expected profitability of litigation to the expected profitability of commercialization. Low-type innovators will nearly always litigate. Furthermore, especially high-type innovators will commercialize, but will be litigated often: Even if the high-type's patent portfolio is dissimilar to the low-type's (so the litigation's probability of success is low), the potential payoff of litigation could be high enough to induce suit. Thus, our model predicts that targeted firms should be those cash-rich enough to fund payoffs and those most likely to settle or lose the case for any reason (even if they have less cash).

An interesting implication of the model is that the endogenous emergence of patent trolls causes socially inefficient outcomes by ensuring that some welfare-increasing innovations are not brought to market. These social losses come from two sources: first, from innovators with profitably commercializable inventions but with a high enough probability of being sued to be deterred from production; second, from innovators that decide not to commercialize because the ex ante expected profitability of becoming a patent troll is higher than that of commercialization.

Using proprietary data, we provide strong empirical evidence for the model's main predictions. We link patent-level data on NPEs and their activities to data on all publicly traded firms. Using this linked data, we show that NPEs behave opportunistically; that is, typically acting as patent trolls. Specifically: NPEs target firms that are flush with cash (controlling for all other characteristics) and firms that have had recent, positive cash shocks. 
Indeed, a one standard-deviation increase in cash level increases the probability of being sued by an NPE by $11 \%(t=6.84)$. Given that the mean probability is $2 \%$, this is more than a fivefold increase.

In fact, NPEs even target conglomerate firms that earn all of their cash from segments having nothing to do with the allegedly infringing patents. For example, an NPE is likely sue a firm regarding a technology patent even if the firm is earning all its revenue from a lumber division entirely unrelated to the allegedly infringing technology patent - even if the division holding that patent is unprofitable. Indeed, we find that profitability in unrelated businesses is almost as predictive of NPE infringement lawsuits as is profitability in the segment related to the allegedly infringing patent.

Consistent with our model, we also find that NPEs target firms against which they have a higher ex ante likelihood of winning. We demonstrate this fact using multiple measures of ex ante likelihood of lawsuit success. First, we show that NPEs are significantly more likely to target firms that are busy dealing with a number of other litigation events unrelated to intellectual property. Being tied up with outside litigation roughly doubles the probability $(t=2.87)$ of being sued by an NPE. Moreover, we show that, controlling for all other characteristics, firms with larger legal teams have a significantly lower probability of being targeted by NPEs, consistent with large legal teams serving as a deterrent.

Of course, the true prediction of our model is on the ex ante expected profitability of NPE litigation. To capture this, we interact our measures of expected cash payouts with our measures of expected lawsuit success. We find that, as the model predicts, NPEs systematically target those firms for which the ex ante expected profitability of litigation is large. In particular, the payoutprobability interaction terms are significant and economically large. Our finding suggests that nearly all the firms targeted by NPEs have large pools of cash for potential payouts and are ex ante more likely to pay off in some form (either an out-of-court settlement or an in-court loss). To further explore this connection, we construct a measure of the ex ante expected outcome if a targeted firm were to go to court. This measure 
relies on the assumption that defendants often make predictions about the likely outcome based on observations of other firms in the same industry and location. We find that the interaction term of this expected outcome and expected payout is again large and significant, providing further evidence that NPEs choose targets based on expected profitability: suits with high probability of payoff against firms with deep pockets.

Non-practicing entities don't have a monopoly on IP litigation. Practicing entities (PEs), such as IBM and Intel, also sue each other for patent infringement. If our results are simply picking up general characteristics of IP litigation, then we might expect to see PEs behaving in much the same way as NPEs. In order to compare PE and NPE behavior, we hand-collected the universe of patent infringement cases brought by PEs against other PEs in the same period (2001-2011). However, we find the opposite. If anything, PEs are slightly less likely to sue firms with high cash balances and less likely to sue firms with many ongoing cases. All of the other determinants of NPE targeting have (statistically and economically) no impact on PE litigation behavior. This comparison suggests that our results on NPE litigation behavior are not just reflections of general characteristics of IP litigation. Rather, our findings are consistent with agent-specific motivations for NPEs in targeting firms flush with cash just when favorable legal outcomes are more likely.

Lastly, we examine the real impacts of NPEs' litigation activity. Comparing firms that are sued by NPEs and go to court (and in this way controlling for selection of firms targeted by NPEs), we find that firms that lose in court have significantly lower post-litigation patenting activity and fewer citations to their marginal post-litigation patents, relative to firms whose cases are dismissed. Furthermore, after losing to NPEs, firms significantly reduce R\&D spending - both projects inside the firm and acquiring innovative R\&D projects outside the firm. Our evidence suggests that it really is the NPE litigation event that causes this decrease in innovation. ${ }^{3}$ Prior to litigation, firms that subsequently lose to NPEs are identical to those

\footnotetext{
${ }^{3}$ Of course, when NPEs win suits, some of the losses to the practicing entity - that is, the awarded damages but not the legal costs - will go back to the NPEs. Potentially, those funds could flow back to the end-innovators, fueling further invention. Estimates are, however, that only five cents of every dollar in damages won by NPEs actually is paid back to innovators (Bessen and Meurer, 2014).
} 
that subsequently have suits dismissed. They have the same R\&D, patenting, and patent quality. Moreover, patents of firms developed pre-litigation continue to accrue citations at exactly the same rate after litigation, whether or not the suit was dismissed. This is in stark contrast to the divergent amount of citations of firms' post-litigation patents.

Taken as a whole, our evidence appears most consistent with the view that NPEs behave as patent trolls. Alternative interpretations simply do not seem to explain our entire body of evidence. For instance, the possibility that targeted firms know they are infringing and therefore raise cash against anticipated litigation might be consistent with our results on cash-targeting; however, this view is completely at odds with our finding that firms that significantly reduce their legal representation are NPEs' main targets. Meanwhile, the idea that NPEs solely target firms that profitability infringe on NPE intellectual property is largely inconsistent with our finding that profitability in unrelated operating segments is almost as predictive of suit as profitability in the targeted patents' segments.

The remainder of the paper proceeds as follows. Section 1 provides background and a literature review. Section 2 develops a model of the economics of innovation and the endogenous evolution of patent trolls. Section 3 describes the proprietary data that we use. Section 4 presents the main empirical results on NPE targeting. Section 5 shows evidence on the real impacts of NPE litigation behavior on innovation. Section 6 provides a discussion, and Section 7 concludes.

\section{Background}

The amount of patent-related litigation has increased tenfold since 2000. According to a recent Government Accounting Office (2013) report, three factors contributed to this pattern: (1) the number of patents (especially software-related patents) with unclear scope has increased; (2) courts have been awarding large monetary awards in infringement lawsuits, even for ideas that make only small contributions to a product; and (3) markets place a larger valuation on 
patents than they did before.

Large-scale NPE patent litigation is a recent development; thus, the empirical literature on NPEs is limited, but growing rapidly (see Bessen et al., 2011; Galasso et al., 2013; Bessen and Meurer, 2014; Chien, 2014; Scott Morton and Shapiro, 2014; Smeets 2014; Tucker 2014a,b). Our paper contributes to this literature by providing facts about which public corporations NPEs choose litigate, when NPEs litigate those companies, and how NPE litigation impacts innovative activity at targeted firms.

Our work is also related to the literature that examines the choice between settlement and the pursuit of a court decision. Spier (2005) provides an excellent review of the economics of litigation. Previous surveys include those of Cooter and Rubinfeld (1989), Hay and Spier (1998), and Daughety (2000). While we focus solely on intellectual property, our paper is also related to the well-developed literature on the effect of litigation risk on firm activities. ${ }^{4}$

\section{Economics of Innovation and Litigation}

In this section, we present a simple model of innovation commercialization in the shadow of (possible) patent trolling.

Our model illustrates our main empirical predictions: NPEs' lawsuit targeting decisions depend directly on expected profitability of suit, rather than the similarity of targets' inventions to the those of the NPEs. NPEs target the most profitable firms. Meanwhile, NPEs ignore firms with inventions closely to their own because those inventions are not profitable enough to justify suit.

Additionally, our model complements our empirical analysis by highlighting two sources

\footnotetext{
${ }^{4}$ Prior research has investigated the impact of litigation risk on several characteristics, including cash holdings (Arena and Julio, 2010), equity-based compensation (Jayaraman and Milbourn, 2009), IPO underpricing (Lowry and Shu, 2002; Hanley and Hoberg, 2012), institutional monitoring and board discipline (Cheng, Huang, Li, and Lobo, 2010; Laux, 2010), conservatism in debt contracting (Beatty, Weber, and Yu, 2008), audit fees (Seetharaman, Gul, and Lynn, 2002), and auditors' resignation decisions (Shu, 2000). Papers have also investigated the relationship between managers' financial reporting and disclosure decisions and firms' litigation risk (see, e.g., Skinner 1994, 1997; Francis, Philbrick, and Schipper, 1994; Johnson, Kasznik, and Nelson, 2000; Rogers and Van Buskirk, 2009).
} 
of inefficiency from patent trolling:

- Because of patent trolling, innovations of intermediate quality (too low to be unambiguously commercializable, but too high to be "safe" from trolls) are crowded out of the market entirely.

- Innovators may forgo commercialization in favor of trolling.

In our presentation of the model, we abstract away from innovation production by assuming that inventors $i$ are already endowed with inventions of quality $\theta_{i}$. However, our findings are unchanged if we (1) treat $\theta_{i}$ as the expected quality of innovator $i$ 's invention conditional on innovation attempt, and (2) incorporate the costs of innovation into the cost of invention commercialization ( $k$, in the sequel). Thus, our finding on commercialization crowd-out can be interpreted equally well as crowding out of innovative activity. ${ }^{5}$

\subsection{Basic Model}

We consider a simple setup in which there are two inventors. ${ }^{6}$ Each inventor $i$ has an invention $\theta_{i} \in \mathbb{R}$ and can choose between commercializing, suing, or exit. ${ }^{7}$

Commercializing an invention $\theta$ yields profits $\pi(\theta)$, at (fixed) cost $k$. We assume that inventions are ordered by quality so that $\pi$ is increasing. ${ }^{8}$

Suing $\operatorname{costs} c$. If one inventor sues and the other commercializes, then the suing inventor wins his suit with probability $p_{\theta_{i}}\left(\theta_{j}\right) \equiv p\left(\left|\theta_{i}-\theta_{j}\right|\right)$. We assume $p$ is continuous, and that suits

\footnotetext{
${ }^{5}$ We also abstract away from the fact that, often, NPEs are not themselves inventors. This does not meaningfully affect our theoretical findings, as the cost of acquiring patents can be incorporated into the cost of suit $(c$, in the sequel). However, treating NPEs as inventors does mask a third potential source of inefficiency from patent trolling: if NPEs keep some of the proceeds from their lawsuits rather than passing them through to end inventors, then they can inefficiently distort funds away from innovation. We discuss this inefficiency - and try to ballpark its magnitude - in Section 6.

${ }^{6}$ Our approach can be easily extended to a continuum of investors, but all of the important dynamics can be illustrated with the two-inventor case.

${ }^{7}$ We focus only on pure-strategy equilibria. Additionally, we assume that firms cannot commit not to sue.

${ }^{8}$ We treat invention types as unidimensional, effectively focusing on a single category of invention with differentiation only in terms of quality. Our results are unchanged if instead we allow both horizontal and vertical differentiation. Indeed, our results are strengthened if courts may sometimes make errors on the horizontal dimension of innovation, as then inventors holding patents in low-value invention categories can bring patent troll lawsuits against firms that have inventions in higher-value categories.
} 
over identical inventions are always successful, i.e. $p(0)=1$. In principle, distinct inventions should never be determined infringing - fully effective courts would ensure that $p(\theta)=0$ for all $\theta \neq 0$. However, we assume some friction in courts' evaluations of patent similarity, so that $p(\theta)>0$ for all $\theta \in \mathbb{R}$. Nevertheless, we assume that courts can make relative similarity judgments correctly, so that $p$ is decreasing.

If an inventor $i$ wins a suit against the other inventor, $j$, then $i$ is awarded $\omega\left(\pi\left(\theta_{j}\right)\right)$. Here, we assume that $\omega \in(0, \infty)$, so that we express the award as a multiple $\omega$ of the commercial profits $\pi\left(\theta_{j}\right)$. For example, in the case of "trebled" damages, with damages determined equal to the commercial profits $\pi\left(\theta_{j}\right)$ of $j$, we would have $\omega=3$. Suing yields no profits if both inventors choose to sue, or if one inventor chooses to exit.

\subsection{The Born Troll}

First, we consider the case in which one of the inventors, $t$ is a "born troll," whose invention is not valuable enough to commercialize on its own. That is, we assume that $\pi\left(\theta_{t}\right)<k$. In this case, $t$ will always choose either to sue or to exit. In this context, the other inventor, $r \neq t$, will never choose to sue.

We suppose that $r \neq t$ has a potentially profitable invention: $\pi\left(\theta_{r}\right) \geq k$, or equivalently, $\theta_{r}>\pi^{-1}(k)$. We then have $\theta_{t}<\pi^{-1}(k)<\theta_{r}$, so that $p_{\theta_{t}}\left(\theta_{r}\right)$ is decreasing in $\theta_{r}$. There are three cases to consider:

1. If $\theta_{r}<\pi^{-1}\left(\frac{c}{\omega p_{\theta_{t}}\left(\theta_{r}\right)}\right)$, then $\omega\left(\pi\left(\theta_{r}\right)\right) \cdot p_{\theta_{t}}\left(\theta_{r}\right)<c$, so that suit is never profitable for $t$. In this case, $r$ can commercialize without fear of suit, and will choose to do so. ${ }^{9}$

2. If $\pi^{-1}\left(\frac{c}{\omega p_{\theta_{t}}\left(\theta_{r}\right)}\right)<\theta_{r}$ and $\theta_{r}<\pi^{-1}\left(\frac{k}{1-\omega p_{\theta_{t}}\left(\theta_{r}\right)}\right)$, then $c<\omega\left(\pi\left(\theta_{r}\right)\right) \cdot p_{\theta_{t}}\left(\theta_{r}\right)$ - suit is profitable - and $\pi\left(\theta_{r}\right)-k<\omega\left(\pi\left(\theta_{r}\right)\right) p_{\theta_{t}}\left(\theta_{r}\right)$ - commercialization is not profitable for $t$,

\footnotetext{
${ }^{9}$ The range of inventions $\theta_{r}$ which are commercialized without drawing suit expands, holding $p$. fixed, as
}

- the cost of commercialization, $k$, falls;

- the cost of suit, $c$, rises; or

- the returns from suit $\omega$ fall. 
given that $i$ gets sued. In this case, inventor $r$ has a profitable invention but chooses not to commercialize; this is socially inefficient(!). ${ }^{10}$

3. If $\pi^{-1}\left(\frac{c}{\omega p_{\theta_{t}}\left(\theta_{r}\right)}\right)<\theta_{r}$ and $\pi^{-1}\left(\frac{k}{1-\omega p_{\theta_{t}}\left(\theta_{r}\right)}\right)<\theta_{r}$, then $c<\omega\left(\pi\left(\theta_{r}\right)\right) \cdot p_{\theta_{t}}\left(\theta_{r}\right)$ - suit is profitable - and $\omega\left(\pi\left(\theta_{r}\right)\right) p_{\theta_{t}}\left(\theta_{r}\right)<\pi\left(\theta_{r}\right)-k$ - commercialization is profitable for $t$ even given suit. In this case, $r$ will choose to commercialize, and $t$ will sue him.

If $\omega p_{\theta_{t}}\left(\theta_{r}\right) \geq 1$, then $\theta_{r}<\pi^{-1}\left(\frac{k}{1-\omega p_{\theta_{t}}\left(\theta_{r}\right)}\right)$ a priori, so commercializing cannot be profitable in the presence of suit. Thus, we assume $\omega p_{\theta_{t}}\left(\theta_{r}\right)<1$ in the sequel.

Now, suit occurs in equilibrium if and only if

$$
\theta_{r}>\max \left\{\pi^{-1}\left(\frac{c}{\omega p_{\theta_{t}}\left(\theta_{r}\right)}\right), \pi^{-1}\left(\frac{k}{1-\omega p_{\theta_{t}}\left(\theta_{r}\right)}\right)\right\}>\pi^{-1}(k) .
$$

Thus, there is a range of inventions $\theta_{r}$ for which

$$
\theta_{t}<\pi^{-1}(k)<\theta_{r}<\max \left\{\pi^{-1}\left(\frac{c}{\omega p_{\theta_{t}}\left(\theta_{r}\right)}\right), \pi^{-1}\left(\frac{k}{1-\omega p_{\theta_{t}}\left(\theta_{r}\right)}\right)\right\}
$$

Any inventions $\theta_{r}$ in the range $(2)$ for which $\theta_{r}<\pi^{-1}\left(\frac{c}{\omega p_{\theta_{t}}\left(\theta_{r}\right)}\right)$ - that is, any inventions $\theta_{r}$ for which $\theta_{r}>p_{\theta_{t}}^{-1}\left(\frac{1}{\omega} \frac{c}{k}\right)$-are commercialized (case 1 above). There are commercialized inventions that do not draw suit even though they are "closer" to $\theta_{t}$ than the inventions that do draw suit. Because $\theta_{t}$ is a low-value invention, the inventions most similar to $\theta_{t}$ are not worth trolling.

Now, as $c \rightarrow 0$, the $\pi^{-1}\left(\frac{k}{1-\omega p_{\theta_{t}}\left(\theta_{r}\right)}\right)<\theta_{r}$ condition must bind in (1). Thus for any sufficiently valuable invention that is commercialized - no matter how unlikely to be confused with $\theta_{t}$-it is possible to make the costs of suit $c$ low enough that $t$ will sue $r$.

An increase in $\omega p_{\theta_{t}}\left(\theta_{r}\right)$ towards 1 increases crowd-out on both the low and high margins: The range of inventions $\theta_{r}$ for which $\theta_{r}<\pi^{-1}\left(\frac{c}{\omega p_{\theta_{t}}\left(\theta_{r}\right)}\right)$ shrinks, so fewer inventions can

\footnotetext{
${ }^{10}$ Note that this result is preserved even if we allow mixed strategies. Indeed, if $r$ can mix between suing and exiting, then he will sue just frequently enough to ensure that $r$ is indifferent between commercializing and not commercializing.
} 
be commercialized without fear of suit. Meanwhile, the range of inventions $\theta_{r}$ for which

$\pi^{-1}\left(\frac{k}{1-\omega p_{\theta_{t}}\left(\theta_{r}\right)}\right)<\theta_{r}$ also shrinks-inventions that were previously profitable (given suit) become unprofitable (given suit). Thus, increases in $\omega$, the returns from suit, and pointwise dominant increases (i.e. rightward shifts) in $p_{\theta_{t}}(\cdot)$, the probability of successful suit, are socially inefficient. It is not clear, however, that such shifts will produce more suits in aggregate because inventions that might have drawn suit are crowded-out.

\subsection{The Opportunistic Inventor}

Now, we suppose that both inventors have potentially profitable inventions, but that one of the inventors, $t$, has an much less valuable than that of the other inventor, $r$. We focus on one particular region of interest, in which $t$ chooses not to commercialize and instead sues $r$. Specifically, we assume:

- $\theta_{r}>\theta_{t}>\pi^{-1}(k)$ (both inventions are potentially profitable);

- $\pi\left(\theta_{r}\right)-k-\omega\left(\pi\left(\theta_{r}\right)\right) p_{\theta_{t}}\left(\theta_{r}\right)>\max \left\{\omega\left(\pi\left(\theta_{t}\right)\right) p_{\theta_{r}}\left(\theta_{t}\right)-c, 0\right\}=\max \left\{\omega\left(\pi\left(\theta_{t}\right)\right) p_{\theta_{t}}\left(\theta_{r}\right)-c, 0\right\}$ (commercialization is the most profitable option for $r$, even given the possibility of suit and the option of suing $t$ ); and

- $\omega\left(\pi\left(\theta_{r}\right)\right) p_{\theta_{t}}\left(\theta_{r}\right)-c>\pi\left(\theta_{t}\right)-k$ (if $r$ commercializes, then suing is unambiguously the most profitable option for $t$ ).

With these assumptions, $r$ always commercializes and $t$ always sues $r$ instead of commercializing. Even though $t$ has a socially valuable invention, the high expected returns from suing a much more profitable inventor lead $t$ to become an "endogenous troll." 


\section{Data}

We obtain information on NPEs from PatentFreedom, a company that tabulates information on NPE behavior, including data on patent litigation. ${ }^{11}$ PatentFreedom has collected data going back to 1977, capturing from Public Access to Court Electronic Records (PACER) every litigation filed by more than 4000 NPEs (approximately 850 parent companies, and 3300 affiliates); the data is thus systematic, and not based on self-reporting. PatentFreedom cleans its raw filing data (for instance, removing some "administrative duplicates" representing the same case, but moved across districts).

Patent assertions by NPEs (e.g., "demand letters"), while not formal legal actions, do occur. Patent assertions are unreported by nature, so there is unfortunately no comprehensive dataset of these actions. However, it is widely believed that informal patent assertions has been in decline recently, and is projected to decline further. The two biggest factors driving this decline are the decreasing credibility of patent assertion (given the availability of formal legal channel), ${ }^{12}$ and the rise of legislation (both state and federal) to hold entities liable for unsubstantiated demand letters. ${ }^{13}$ Furthermore, as many more NPEs are now suing (see Table I), non-legally binding letters simply claiming infringement (and asking for money) are becoming less credible signals. The equilibrium result is that the economically large alleged IP infringements appear to be addressed through lawsuits (all of which in our data), and this is becoming increasingly true over time. We thus feel that PatentFreedom's systematic and exhaustive collection of NPE lawsuit data likely captures an important, economically important (and increasingly dominant) component of NPE behavior, even though it does not fully capture patent assertions (which, again, appear to be on the decline).

\footnotetext{
${ }^{11}$ PatentFreedom defines an NPE as "A firm that derives the majority of its revenue from licensing and enforcement of patents." Under this definition, traditional legal entities established to license and enforce patents encompass the majority of NPEs. Additionally, individual inventors may be counted, while universities will not be counted (unless they have enforcement subsidiaries).

${ }^{12}$ One company executive relayed to us his reply to NPEs that send demand letters: "If you have a truly viable case you will sue; otherwise don't waste my time with this letter(!)."

${ }^{13}$ See, e.g., Executive Office of the President 2013 report on Patent Assertion and U.S. Innovation, http: //www.whitehouse.gov/sites/default/files/docs/patent_report.pdf (accessed on March 5, 2014).
} 
According to PatentFreedom, roughly $69 \%$ of NPEs patents were acquired externally (purchased) by the NPEs and their subsidiaries, whereas 19\% were originally assigned to them. ${ }^{14}$ The data also provide detailed information on 11,838 litigations, again which PatentFreedom obtained from the Public Access to Court Electronic Records (PACER) database. In 10,933 of these cases, an NPE was the plaintiff. We focus on the 3,683 cases in which the defendant firm was publicly traded.

We obtain firm-level patent information from the database used by Kogan et al. (2012). ${ }^{15}$ This database contains utility patents issued by the United States Patent and Trademark Office (USPTO) between January 1, 1926 and November 2, 2010, along with citation data on those patents. ${ }^{16}$ We obtain information on the in-house legal counsels and law firm associations of public firms from ALM Legal Intelligence, which searches public records to find outside counsel used by companies for corporate, contract, labor, tort, and IP litigation.

To identify involvement in litigation events not related to IP, we use the Audit Analytics Litigation database, which covers the period from 2000 to 2012 and reports information on litigation for Russell 1000 firms from legal disclosures filed with the SEC. Audit Analytics collects details related to specific litigation, including the original dates of filing and locations of litigation; information on plaintiffs, defendants, and judges; and, if available, the original claim amounts and the settlement amounts.

In Table I (Panel A), we present summary statistics on the firms included in our analysis. ${ }^{17}$ Consistent with the overall trend that the amount of patent litigation has increased over time, we find that the number of public firms sued by NPEs has increased over time (see

\footnotetext{
${ }^{14}$ See https://www . patentfreedom.com/about-npes/background/ (accessed on March 5, 2014). The remaining $12 \%$ are a blend of originally assigned and acquired patents.

${ }^{15}$ We thank Leonid Kogan, Amit Seru, Noah Stoffman and Dimitris Papanikolaou for providing both patent and citation data.

${ }^{16}$ USPTO defines utility patents as patents issued for the invention of a new and useful process, machine, manufacture, or composition of matter, or a new and useful improvement thereof, it generally permits its owner to exclude others from making, using, or selling the invention for a period of up to twenty years from the date of patent application filing. Approximately $90 \%$ of the patent documents issued by the USPTO in recent years have been utility patents.

${ }^{17}$ Appendix Table A1 contains detailed descriptions of the specific data fields used in our study.
} 
Panel B). ${ }^{18}$

\section{Results}

\subsection{Ability to Pay for Monetary Damages}

We begin by testing the central prediction of our model; namely, that NPEs target firms with the ability to pay large damages or settlement fees. We use both level of cash balances (CashLevel) on the balance sheet and changes in cash holdings (CashShock) as proxies for the potential proceeds of a suit ( $\omega \pi$ from Section 2$)$. We include several firm- and time-level control variables, such as the firm's market value, book-to-market ratio, ${ }^{19}$ prior year's stock market performance, and number of recent patent filings, along with time and firm fixed effects. In Table II, we report OLS regression results of the following specification:

SuedByNPE $=f($ TotalAssets, MarketValue, BM, PastReturn, PatentStock, CashLevel, CashShock).

The outcome variable, SuedByNPE, is a dummy equal to 1 if the firm was litigated by an NPE in a particular year. CashLevel is the total amount of cash reported on the balance sheet as of the beginning of the previous fiscal year. CashShock is a dummy variable equal to 1 if the change in cash in the most current fiscal year, compared to the previous fiscal year's cash level, is among the top $90 \%$ of cash changes in the cross-section. We include firm fixed effects to capture unobserved firm-level time-invariant factors that are correlated with NPE targeting. Likewise, we include time fixed effects to control for variation in litigation activity specific to a given year and for any time trends in litigation propensity. We report various specifications to show the incremental value of each covariate on overall model fit. Column 5 of Table II represents our preferred specification, which includes firm-level characteristics

\footnotetext{
${ }^{18}$ As a docket (case) can have multiple defendants and the same defendant can be sued multiple times in a year, the firm-years presented in Panel B encompass our 3,683 cases.

${ }^{19}$ We use Tobin's Q to proxy for investment opportunities.
} 
(market value, book-to-market ratio, asset size, prior stock performance of equity), time and firm fixed effects, and our cash variables. We use a log transformation of all variables to minimize the effect of outliers. ${ }^{20}$ We cluster our standard errors at the firm level in order to broadly allow for any time-series dependency in the probability of being sued over the course of the sample period.

Table II provides strong evidence consistent with the model's central prediction; namely, firms with large cash balances and firms experiencing a shock to their cash holdings are more likely to be targeted by NPEs. For instance, controlling for other determinants and for firm and time fixed effects, the CashLevel coefficient in Column 3, $0.1046(t=6.79)$, is large and significant, as is the CashShock coefficient in Column 4, $0.0167(t=1.99)$. To get an idea of the magnitudes, we use the coefficient estimates in the full specification in Column 5. With the average firm-level cash holding of $\$ 0.30$ billion, the $0.1063(t=6.84)$ coefficient on CashLevel implies that a one standard-deviation increase in cash balance increases the chances of being sued by $11.10 \%$. Given that the unconditional probability of being sued for patent infringement is approximately $2.18 \%$, this is more than five times the risk that the average firm faces. The coefficient on CashShock, $0.0213(t=2.55)$, implies that the probability of being sued nearly doubles after a cash shock. Both of these estimates show the large economic impact of cash on NPE targeting.

In terms of control variables, the probability of being sued by an NPE is positively correlated with the level of R\&D activity, as measured by the number of patents filings in the past five years $(0.0064, t=2.68)$. Once we include firm fixed effects and control for CashLevel, we find that firms with smaller market capitalization are slightly more likely to be targeted by NPEs $(-0.0049, t=2.17)$.

In sum, Table II reveals the strong impact of cash on NPEs' targeting decisions. In particular, in Column 5, both of these effects are estimated including firm and time fixed effects, along with fine controls for firm size, past returns, and patent stock. Thus, the large

\footnotetext{
${ }^{20}$ Neither the magnitudes nor the significance of our coefficients change appreciably when we do not use log transformation (see Online Appendix).
} 
coefficients can be interpreted as showing that a firm is likely to be targeted by NPEs when it has an abnormally high cash level (or a shock to that cash level) relative to all other firms' relative cash levels (and shocks).

\subsection{Probability of Paying}

A United States inventor's patenting process begins with an application to the United States Patent and Trademark Office, which assigns it to a patent examiner, whose job is to compare its claims to prior art in order to determine whether the claimed invention is novel and nonobvious. $^{21}$ If the examiner decides to grant the claims in the application, USPTO issues a patent to the applicant. ${ }^{22}$ The patentability of a patent's claims can be challenged in administrative proceedings before USPTO. Patent validity can be challenged in one of the 94 federal district courts by presenting a prior art that may have been overlooked by USPTO examiners.

Since a patent confers the right to exclude others from "practicing" an invention, patent owners can sue anyone who uses, makes, sells, offers to sell, or imports their inventions without legal permission. If a patent infringement lawsuit is not dismissed in its initial stages, it proceeds to the discovery phase, in which both the accused infringer (defendant) and the patent owner (plaintiff) supply documents intended to demonstrate how the allegedly infringing product is made. If a party does not make or sell products or provide services based on the patented invention, then it is likely to have far fewer documents to disclose. Consequently, as NPEs do not produce products, going into the discovery phase can be far less costly for them than for defendants.

If an infringement suit is not settled during the discovery phase, the judge interprets the parties' claims, making a determination as to whether the patent is found both valid and

\footnotetext{
${ }^{21}$ Prior art refers to other patents, publications, and publicly disclosed but unpatented inventions that predate the patent application's filing date.

${ }^{22}$ In 2013, the average time between application and initial examiner report was 18.2 months and, on average, it took 29.1 months for USPTO to issue a patent. For other USPTO-related statistics, see http://www. uspto.gov/about/stats/.
} 
infringed. A judge who rules in favor of the patent owner can award monetary damages and/or issue an injunction to prohibit further infringement.

Our model suggests that NPEs will be opportunistic in picking patents to litigate, maximizing the expected profitability of winning. Our results in Section 4.1 show that NPEs target the firms against which litigation will be most profitable conditional on lawsuit success. In this section, we show moreover that NPEs are most likely to target firms against which they have a high probability of winning (either through settlement or in court).

We introduce two measures of an NPE's ex ante probability of success in litigation $(p)$. The first is based on the idea that firms differ in their readiness to stave off litigation events. Firms anticipating litigation are more likely to show evidence of advanced preparation; such defense mechanisms are likely to deter NPEs because they stand to prolong the court (or settlement) process. We use the number of "excess lawyers" as our measure of litigationreadiness. Because the number of lawyers can vary with respect to firm characteristics, we first build a model to estimate the number of lawyers a firm would employ given its observable characteristics. Specifically, we regress (log) NumberOfLawyers on firms' intellectual property holdings $(\log ($ PatentStock $))$ and on the presence of in-house counsel (In-HouseCounsel), a department of lawyers housed inside the firm who handle its most frequent legal issues. Firms performing badly in equity markets have been found to be slightly more likely to be sued (Dyl, 1999; Simmons and Hoyt, 1993; Gande and Lewis, 2009); hence, we include past performance. Finally, we include (a) firm fixed effects to capture time-invariant unobserved firm-level characteristics that can be related to NumberOfLawyers and (b) year fixed effects to capture variation in demand for lawyers over time.

Appendix Table A2 shows the results of the model we estimate to predict the expected number of lawyers a firm hires, given covariates. As expected, the number of lawyers is negatively correlated with past equity return and positively correlated with R\&D activity, as measured by PatentStock. We calculate ExcessLawyers by subtracting the predicted number of lawyers from the actual number of lawyers. We take ExcessLawyers as a measurement of 
potential deterrence to NPEs; in principle, it decreases the probability of success an NPE can expect in targeting a given firm.

Our second measure uses the within-firm resource constraint on time and proceeds spent battling litigation. Based on this, we predict that a firm is likely to focus less attention on the marginal case if it is already occupied with other types of litigation. We therefore use the existence of non-IP-related litigation (OngoingCases) as a measure of an NPE's likelihood of targeting a firm, since firms dealing with such litigation may be more likely to settle or less focused in court. A lack of focus in court would, in turn, give NPEs, holding all else fixed, a higher subjective probability of winning.

Using these two measures, we test our model's prediction that, conditional on the potential proceeds if the NPE wins a given suit ( $\omega \pi$, in our model), NPEs should target firms that offer a higher ex ante probability of a successful litigation outcome. We supplement our main specification (as reported in Table III) with the two measures of ex ante probability of suit success:

$$
\begin{array}{r}
\text { SuedByNPE }=f(\text { TotalAssets, MarketValue, BM, PastReturn, PatentStock, CashLevel, } \\
\text { CashShock, ExcessLawyers, OngoingCases }) .
\end{array}
$$

The results of these tests are reported in Table III. The coefficient estimate on ExcessLawyers is negative $(-0.1295, t=-2.31)$, consistent with a deterrent effect of a large legal team. The coefficient implies that a one standard-deviation increase in excess lawyers is associated with a $0.5 \%$ decrease in the chance of being targeted by an NPE. The coefficient on OngoingCases is positive and significant. Given the firm fixed effects, that coefficient- $0.0167(t=2.87)$ from Column 4-implies that when a firm has a slate of ongoing cases, it has a 1.67\% higher chance of being targeted by an NPE (against a mean of roughly 2\%), controlling for CashLevel and CashShock. Overall, these results suggest that NPEs target firms a with higher likelihood of settling. 
Of course, the true prediction of our model is the overall expected profitability of targeting a given firm: the product of $\omega \pi$ (proceeds) and $p$ (probability of winning). Empirically, this equates to the interaction between our measures of proceeds (CashLevel and CashShock) and of probability of success (ExcessLawyers and OngoingCases). In Table IV, we test the impact of overall expected profitability using these interaction effects. The specification is identical to that used in Tables II and III, with the dependent variable being whether or not the given firm was targeted by litigation from an NPE.

The interpretation of each measure in Columns 1-4 is that NPEs are significantly more likely to bring suit as the ex ante expected total profitability of bringing litigation increases. The negative and significant coefficient on (CashLevel ExcessLawyers) implies that NPEs are especially likely to target a firm with a high cash level and a small legal team. The positive and significant coefficients on (CashLevel - OngoingCases) and (CashShock · OngoingCases) similarly indicate that NPEs are especially likely to target a firm that is flush with cash and busy with other cases. $^{23}$

The sum of the evidence in Tables II-IV provides strong support for the main predictions of our model of endogenous patent troll formation. In particular, the evidence suggests that NPEs are behaving precisely as patent trolls would: They target firms that are flush with cash (or that have had recent positive cash shocks), that lack broad legal teams, that are likely to be busy with other cases, and that are from regions and/or industries with strong precedents for successful patent litigation. In the following section, we strengthen this characterization by exploring a particularly egregious NPE behavior: targeting cash that is entirely exogenous to the patent claim.

\footnotetext{
${ }^{23}$ We also create a third measure of ex ante probability, using the evidence on judicial bias (Lerner, 2013) and information on industrially and geographically similar recent case outcomes. We report the results in Appendix Table A3, finding that when NPEs think they are more likely to win a suit against a firm (given the geographic make-up of the court location vis-à-vis the firm, along with the recent track record of success suing firms from that region and industry), they are significantly more likely to bring the suit against the firm - precisely when the firm is flush with cash.
} 


\subsection{Unrelated Profits}

While the evidence presented in the previous section suggests that NPEs exhibit opportunistic behavior in suing alleged patent-infringing firms, it does not suggest that they go after profits unrelated to the patents that have allegedly been infringed. This is because firm-level data do not allow us to extract infringed-patent-related profits from total profits. In this section, we use business-segment disclosures to do exactly that.

This fine empirical specification also allows us to address an identification issue that we could not address with the aggregated cash variables at the firm level. In particular, although all of the results in Table II are consistent with the endogenous patent troll behavior we model in Section 2, an alternative explanation could be that the targeted firms have endogenously realized that they are infringing on patents and have raised cash preemptively as a precautionary savings device. But for this to explain all of our results thus far, firms must raise cash (and have abnormal shocks to cash) precisely before they are sued, controlling for the amount of R\&D activity in which they have engaged. More importantly - and directlyfrom Tables III and IV, we see that under this interpretation, firms would need to raise cash for precautionary savings to preempt litigation at the same time they are actively decreasing their legal representation. This seems counter to the preemptive cash-stockpiling thesis. Instead, our findings are much more consistent with NPEs acting as patent trolls - targeting cash-rich firms that have recently reduced their legal teams.

We are able to provide even cleaner empirical evidence for patent troll behavior using finely reported business-segment data. As of 1976, all firms are required by Statement of Financial Accounting Standards (SFAS) 14 (Financial reporting for segments of a business enterprise, 1976) and SFAS 131 (Reporting desegregated information about a business enterprise, 1998) to report financial information for any industry segment that accounts for more than $10 \%$ of total annual sales.

Using these segment-level filings, we extract information on industry classification, sales, and cost of goods sold for each segment for all conglomerates between 2000 and 2011. We 
then use the concordance between international patent classification (IPC) codes and fourdigit United States Standard Industrial Classifications (SIC) to identify the conglomerates' segments associated with the NPE-litigated patents. ${ }^{24}$

After identifying segments related to allegedly infringed patents, we split each NPEtargeted firm's segments into related segments and unrelated segments. A firm's related segments are those segments that could potentially use the litigated patent in regular operations. Its unrelated segments could not. We compute each segment group's gross profits by subtracting cost of goods sold from segment group sales. ${ }^{25}$

We note that not all conglomerates report segment-level information in the same format. For example, a conglomerate may report information on one segment only, or it may report cost of goods sold for only one of the segments in which it operates. Therefore, our final sample contains only conglomerates for which we have both cost and revenue data on at least one related and one unrelated segment.

We estimate a model to test whether the probability of being sued by an NPE is correlated with profits obtained from unrelated segments, even after controlling for the profitability of related segments. In this model, we include conglomerate fixed effects to control for conglomerate-level unobserved litigation probability. We also control for industry-wide shocks in profitability by including a variable measuring the average profitability of the segment's industry.

The results of our segment-level analysis are shown in Table V. Column 1 shows the basic model, while Column 2 includes conglomerate fixed effects. Both columns tell the same story. As one would expect, RelatedSegmentProfitability is a large and significant predictor of being targeted by NPEs, consistent with the results in Tables II-IV. But so is UnrelatedSegmentProfitability, with nearly the same magnitude and significance. In other

\footnotetext{
${ }^{24}$ The concordance file we use was developed by Silverman (2002) and later improved by Kerr (2008). This concordance has been used in several other studies, including those of McGahan and Silverman (2001) and Mowery and Ziedonis (2001).

${ }^{25}$ While we would ideally prefer to measure cash at the segment level in order to make our segment-level analysis completely analogous to the tests in Tables II-V, segment-level cash variables are not reported. Thus, we use profitability (revenues net of costs) at the segment level to proxy for profitability of suit.
} 
words, NPEs seem not to care where their proceeds come from; an NPE's probability of suing a firm increases with the firm's profits even if those profits are derived from segments exogenous to the patent under litigation. In Column 2, we see that the coefficient on UnrelatedSegmentProfitability, $0.0051(t=2.96)$, implies that, controlling for the profitability of a segment related to the patent allegedly being infringed, a one standard-deviation increase in a completely unrelated segment's profitability increases the chance of being sued by $0.8 \%$ (relative to a mean of $1.8 \%$ ). This compares to an increase in probability of $1 \%$ for the same size increase in a related segment's profitability $(t=2.95)$.

In sum, the results in Table $\mathrm{V}$ provide additional, and perhaps even stronger, evidence that NPEs behave as patent trolls.

\subsection{IP Litigation Behavior of Practicing Entities (PEs)}

Non-practicing entities do not have a monopoly on IP litigation. Practicing entities (PEs) also sue each other for patent infringement. If our results were simply picking up general characteristics of IP litigation, then we might expect to see PEs behaving in much the same way as NPEs. In order to compare PE and NPE behavior, we hand-collected the universe of patent infringement cases brought by PEs against other PEs in the same period (2001-2011).

The time-series of PE litigation presented in Appendix Table A4 shows that PE litigation has no time-series trend; it has remained sTable at roughly 150 cases per year. NPE litigation, in contrast, has seen huge growth during the same period (included in Appendix Table A4 for comparison).

We run a more formal analysis of the determinants of PE lawsuits, using a set-up identical to that used for NPEs in Section 4.1. We replicate the specifications used in Table III, but this time we use SuedByPE as the dependent variable. ${ }^{26}$ The results of this analysis are in Table VI, where we see that PEs behave very differently from NPEs. Nearly all of the predictors of NPE litigation behavior have a small and insignificant impact on PE litigation

\footnotetext{
${ }^{26}$ SuedByPE is a dummy variable equal to 1 if the firm is involved in a PE IP lawsuit in that year, and 0 otherwise.
} 
behavior. Moreover, the impact of cash goes mildly in the opposite direction-PEs tend to sue firms with slightly lower cash levels - as does the impact of OngoingCases-PEs tend to sue firms with fewer ongoing cases.

Our comparison suggests that our results on NPE litigation behavior are not just reflections of general characteristics of IP litigation. Rather, our findings are consistent with agentspecific motivations for NPEs in targeting firms flush with cash just when favorable legal outcomes are more likely.

\section{Impact of Patent Trolling on Real Outcomes}

Our results up to this point suggest that NPEs behave as patent trolls in their litigation behavior. They target firms opportunistically — not on the merits of the case but rather on the ease of extracting rents. Our model predicts that this leads to socially inefficient outcomes, both when firms decide not to pursue profitable innovations because it is ex ante more profitable to be a troll and when firms that would otherwise invent/commercialize decide not to, given the high likelihood of being litigated. Furthermore, in terms of comparative statics, the higher the expected cost of litigation to an innovating firm, the less likely that firm is to innovate and commercialize.

It is difficult to measure the potential innovation that NPE behavior has stifled. Nevertheless, we seek to obtain at least a baseline estimate of how NPEs affect innovative behavior. To do this, we adopt a diff-in-diff approach.

We compare all firms targeted by NPEs. In this subsample, firms are identical in terms of NPEs' target-selection criteria. We separate targeted firms according to whether (1) they were forced to pay out to NPEs (they lost in court or settled) or (2) the cases against them were dismissed. We then test whether losing a case and having a case dismissed lead firms in different directions in terms of future R\&D productivity. Specifically, we focus on how R\&D expenditures on new projects differ (pre- and post-litigation) among the two classes of 
targeted firms. In addition, for the same diff-in-diff set, we examine the effect on tangible outcomes such as additional patents and citations to those patents.

We use firm-level patent information from the database used by Kogan et al. (2012) to analyze two outcomes: the change in the annual flow of firm-level patents (as measured by new patent applications) and the change in the number of patent citations. ${ }^{27}$ These outcome variable choices are motivated by a large past literature studying the efficiency and outcomes of innovation. ${ }^{28}$

Table VII reports the results of a treatment effects model in which we compare the outputs of (1) firms that were forced to pay out to NPEs (they lost in court or settled) and (2) firms that managed to have their cases dismissed. These two types of firm are interesting to compare because they match up in terms of attractiveness for NPE targeting, but one pays the tangible costs of litigation whereas the other pays nothing. ${ }^{29}$

Our sample contains 484 observations (events), of which thirty-five were dismissed. We note that a firm may be sued multiple times in a given year; if at least one of those cases was not dismissed, we classify the event in the "not dismissed" category. After matching firms using our treatment effects model, we compare firms with dismissed cases to firms that lose cases in terms of future patent accumulation and of citations to patents before and after the litigation event. While the pre-litigation trends in patent accumulation, citations, and R\&D expenditures are identical across groups, we see striking differences following litigation.

\footnotetext{
${ }^{27}$ The database, constructed using Google Patents (www.google.com/patents), is made up of all utility patents issued by USPTO between January 1, 1926 and November 2, 2010. We choose to use the Kogan et al. (2012) database over the frequently used NBER U.S. Patent Citations Data File for two reasons: (1) The NBER database ends at the end of 2005 and NPE litigations have become more intensive in recent years and (2) the Kogan et al. (2012) database is more comprehensive in terms of the number of patents it can attribute to public firms. (Table 1 of Kogan et al. (2012) suggests that they were able to match $24 \%$ more patents than NBER.)

${ }^{28}$ See, for example, Griliches (1981, 1984), Pakes (1985), Jaffe (1986), Griliches, Pakes, and Hall (1987), Connolly and Hirschey (1988), Griliches, Hall, and Pakes (1991), Hall (1993a), Hall (1993b), and Hall, Jaffee, and Trajtenberg (2005), showing that patents (and patent citations) are indications of R\&D productivity.

${ }^{29}$ From Panel A of Table VII, two significant predictors of dismissed cases are (a) CashShock and (b) TotalAssets. While statistically significant, the economic magnitude of their predictability is small. This can be seen through the low $R^{2}$ of the predictive model, most of which is coming from the year fixed effects. Further, the two groups of NPE-targeted firms appear otherwise ex ante to be quite similar on observable characteristics.
} 
Specifically, in the years following litigation, firms against whom cases are dismissed produced spent on average $\$ 211$ million $(t=1.96)$ more on $R \& D$ expenditures than firms that lost to NPEs. These firms also spent on average $\$ 49$ million more $(t=2.95)$ to acquire more in process R\&D from outside. ${ }^{30}$ Furthermore, in the years following litigation, firms against whom cases are dismissed produced 63.52 more new patents $(t=2.96)$, and these new patents received 723.98 more citations $(t=3.45)$, relative to the group of firms that suffered the cost of NPE litigation. ${ }^{31}$ These large differences in R\&D expenditure, patent production and in the quality of produced patents do not appear until after NPE litigation.

As a placebo test to confirm that this result is driven by the NPE litigation action and not by a general decline in the losing firms' technological patent portfolios (relative to those of the firms whose cases were dismissed), ${ }^{32}$ we also compare new citations to the vintage patent portfolios (patents obtained before the litigation event) for the two sets of firms. If the decline in innovation is acting solely through the NPE litigation, we should see no difference in citations to these patent portfolios, even after the litigation event. This is precisely what we find in Panel C of Table VII.

In all, the evidence in this section strongly supports the idea that NPEs have a real and negative impact on innovation for United States firms.

\section{Discussion}

We document transfers from PEs to NPEs that appear to substantively reduce PEs' innovative activity. To measure NPEs' net impact on innovation, however, we must also consider the

\footnotetext{
${ }^{30}$ Prior to 2009 (i.e. before effective date of SFAS 142R), General Accepted Accounting Principles required research and development assets acquired in a business combination that have no alternative future use to be measured at their acquisition-date fair values and then immediately charged to expense.

${ }^{31}$ We focus on the two years following the initial filing of the litigation, as the time between filing date and initial discovery phase could be up to a year. Also, because the distributions of the outcome variables (change in patents, change in citations, change in expenditures for R\&D) contain extreme observations, we also redo the analysis winsorizing and excluding extreme observations using cutoff points (suggested by Cook's distance). The magnitudes remain significant and of comparable magnitude.

${ }^{32}$ For instance, it might be that the firms against whom cases were dismissed happen to have more commercializable technology (such as wireless remote technology), while the losing firms have a patent portfolio in decline (such as wired hard-cable).
} 
possibility that litigation proceeds flow back to end-inventors. That said, estimates are that only five cents of every dollar in damages paid by PEs to NPEs makes it back to the end-innovator (Bessen et al., 2014). Thus, one would need to believe in a huge multiplier on this transfer (on the order of $2000 \%$ ) to justify, from a social-welfare perspective, NPE litigation practices as an efficient transfer of the marginal dollar of innovative capital. In addition, the small size of NPEs' transfers to end-innovators also affects the proposed positive incentive effects of NPEs in the policing of patent infringement. If potential innovators are disincentivized from the marginal innovative project because they believe that large, wellfunded organizations might infringe on their patents, the prospect of receiving (through NPE lawsuits) five cents of every dollar of the innovation's value would do little to re-incentivize them.

\section{Conclusion}

We provide the first large-sample evidence on the litigation behavior of NPEs. We show precisely which corporations NPEs target, when NPEs litigate, and how NPE litigation impacts the innovative activity of targeted firms. We build a parsimonious model of an innovative economy to better understand NPEs' roles, incentives, and welfare impact. We present strong empirical evidence supporting the model's main predictions: NPEs behave, on average, as patent trolls. NPEs target firms that are flush with cash or that have just had positive cash shocks. NPEs even target conglomerate firms that earn their cash from segments having nothing to do with their allegedly infringing patents. Profitability in unrelated businesses is almost as predictive of an NPE suit as is profitability in business segments related to NPE-alleged patent infringement. Additionally, NPEs target firms they expect are more likely to lose in litigation (either in court or through settlement). NPEs target firms that are tied up with litigation outside of the intellectual property space and firms that have abnormally small legal teams. Lastly, we find that the litigation behavior of 
NPEs has negative real consequences on innovation activity. In particular, after losing to NPEs in court, targeted firms innovate less and have lower-quality innovations.

The stakes of how to organize intellectual property disputes are massive. If the United States becomes a less desirable place to innovate because NPEs are left unchecked, innovation and human capital — and the returns to that innovation and human capital — will likely flee overseas. That said, innovators will also leave if they feel they are not are protected from large, well-funded interests that might infringe on innovative capital without recourse. Our results provide evidence that NPEs do not protect innovators from large interests. Rather, our results are consistent with the view that, on average, NPEs behave as patent trolls that chase cash and negatively impact future innovation. Given our findings, the marginal policy response should be to more carefully limit the power of NPEs or, in the framework of our model, increase the cost of bringing suit against commercializers of innovative ideas. 


\section{References}

Arena, M. and B. Julio (2011). Litigation risk, cash holdings, and corporate investment. Working Paper, Marquette University and London Business School.

Bessen, J. E. and M. J. Meurer (2014). The direct costs from NPE disputes. Cornell Law Review 99(2), 387-424.

Bessen, J. E., M. J. Meurer, and J. L. Ford (2011). The private and social costs of patent trolls. Regulation 34(4), 26-35.

Brown, S. V. and J. W. Tucker (2011). Large-sample evidence on firms year-over-year MD\&A modifications. Journal of Accounting Research 49(2), 309-346.

Cheng, A., H. He Huang, Y. Li, and G. Lobo (2010). Institutional monitoring through shareholder litigation. Journal of Financial Economics 95(3), 356-383.

Chien, C. (2014). Startups and patent trolls. Stanford Technology Law Review 17, 461-506.

Cohen, L., K. Diether, and C. Malloy (2013). Misvaluing innovation. Review of Financial Studies 26(3), 635-666.

Cohen, L. and D. Lou (2012). Complicated firms. Journal of Financial Economics 104(2), 383-400.

Connolly, R. A. and M. Hirschey (1988). Market value and patents: A Bayesian approach. Economics Letters 27(1), 83-87.

Cooter, R. D. and D. L. Rubinfeld (1989). Economic analysis of legal disputes and their resolution. Journal of Economic Literature 27(3), 1067-1097.

Daughety, A. F. and J. F. Reinganum (2000). On the economics of trials: Adversarial process, evidence, and equilibrium bias. Journal of Law, Economics, and Organization 16(2), 365-394. 
Dyl, E. A. (1999). Estimating economic damages in class action securities fraud litigation. Journal of Forensic Economics 12(1), 1-11.

Farrell, J. and C. Shapiro (2008). How strong are weak patents? American Economic Review 98(4), 1347-1369.

Francis, J., D. Philbrick, and K. Schipper (1994). Shareholder litigation and corporate disclosures. Journal of Accounting Research 32(2), 137-164.

Galasso, A., M. Schankerman, and C. J. Serrano (2013). Trading and enforcing patent rights. RAND Journal of Economics 44(2), 275-312.

Gande, A. and C. M. Lewis (2009). Shareholder-initiated class action lawsuits: Shareholder wealth effects and industry spillovers. Journal of Financial and Quantitative Analysis 44(4), $823-850$.

Griliches, Z. (1981). Market value, R\&D, and patents. Economics Letters 7(2), 183-187.

Griliches, Z. (Ed.) (1984). RED, Patents and Productivity. University of Chicago Press.

Griliches, Z., B. H. Hall, and A. Pakes (1991). R\&D, patents, and market value revisited: Is there a second (technological opportunity) factor? Economics of Innovation and New Technology $1(3), 183-201$.

Griliches, Z., A. Pakes, and B. H. Hall (1988). The value of patents as indicators of inventive activity. NBER Working Paper No. 2083.

Hall, B. H. (1993). The stock market's valuation of R\&D investment during the 1980's. American Economic Review 83(2), 259-264.

Hall, B. H., A. B. Jaffe, and M. Trajtenberg (2005). Market value and patent citations. RAND Journal of Economics 36(1), 16-38. 
Hall, B. H., E. Mansfield, and A. B. Jaffe (1993). Industrial research during the 1980s: Did the rate of return fall? Brookings Papers on Economic Activity: Microeconomics 1993(3), 289-343.

Hanley, K. W. and G. Hoberg (2012). Litigation risk, strategic disclosure and the underpricing of initial public offerings. Journal of Financial Economics 103(2), 235-254.

Hay, B. and K. E. Spier (1998). Settlement of litigation, Volume 3, pp. 442-451. Palgrave Macmillan.

Jaffe, A. B. (1986). Technological opportunity and spillovers of R\&D: Evidence from firms' patents, profits and market value. NBER Working Paper No. 1815.

Jayaraman, S. and T. Milbourn (2009). Does equity-based CEO compensation really increase litigation risk? Working paper, Washington University.

Johnson, M. F., R. Kasznik, and K. K. Nelson (2000). Shareholder wealth effects of the private securities litigation reform act of 1995. Review of Accounting Studies 5(3), 217-233.

Kasznik, R. and B. Lev (1995). To warn or not to warn: Management disclosures in the face of an earnings surprise. Accounting Review $70(2), 113-134$.

Kerr, W. R. (2008). Ethnic scientific communities and international technology diffusion. Review of Economics and Statistics $90(3), 518-537$.

Kim, I. and D. J. Skinner (2012). Measuring securities litigation risk. Journal of Accounting and Economics 53(1), 290-310.

Kogan, L., D. Papanikolaou, A. Seru, and N. Stoffman (2012). Technological innovation, resource allocation, and growth. NBER Working Paper No. 17769.

Lerner, J. (2010). The litigation of financial innovations. Journal of Law and Economics $53(4)$, 7. 
Lowry, M. and S. Shu (2002). Litigation risk and IPO underpricing. Journal of Financial Economics 65(3), 309-335.

McGahan, A. M. and B. S. Silverman (2001). How does innovative activity change as industries mature? International Journal of Industrial Organization 19(7), 1141-1160.

Mowery, D. C. and A. A. Ziedonis (2001). The geographic reach of market and non-market channels of technology transfer: Comparing citations and licenses of university patents. NBER Working Paper No. 8568.

Noel, M. and M. Schankerman (2013). Strategic patenting and software innovation. Journal of Industrial Economics 61(3), 481-520.

Pakes, A. (1985). On patents, R\&D, and the stock market rate of return. Journal of Political Economy 93(2), 390-409.

Rogers, J. L. and A. Van Buskirk (2009). Shareholder litigation and changes in disclosure behavior. Journal of Accounting and Economics 47(1), 136-156.

Scott Morton, F. M. and C. Shapiro (2014). Strategic patent acquisitions. Antitrust Law Journal 79(2), 463-500.

Seetharaman, A., F. A. Gul, and S. G. Lynn (2002). Litigation risk and audit fees: Evidence from UK firms cross-listed on US markets. Journal of Accounting and Economics 33(1), $91-115$.

Silverman, B. S. (1999). Technological resources and the direction of corporate diversification: Toward an integration of the resource-based view and transaction cost economics. Management Science 45(8), 1109-1124.

Silverman, B. S. (2003). Technological resources and the logic of corporate diversification. Routledge. 
Simmons, R. W. and R. C. Hoyt (1993). Economic damage analysis in rule 10b-5 securities litigations. Journal of Legal Economics 3, 71.

Skinner, D. J. (1994). Why firms voluntarily disclose bad news. Journal of Accounting Research 32(1), 38-60.

Skinner, D. J. (1997). Earnings disclosures and stockholder lawsuits. Journal of Accounting and Economics 23(3), 249-282.

Smeets, R. (2014). Does patent litigation reduce corporate R\&D? an analysis of US public firms. Working Paper, Rutgers University.

Spier, K. (2005). Economics of litigation. In S. Durlauf and L. Blume (Eds.), The New Palgrave Dictionary of Economics. Macmillan.

Tucker, C. E. (2014a). The effect of patent litigation and patent assertion entities on entrepreneurial activity. Working Paper, Massachusetts Institute of Technology.

Tucker, C. E. (2014b). Patent trolls and technology diffusion: The case of medical imaging. Working Paper, Massachusetts Institute of Technology.

Zhan Shu, S. (2000). Auditor resignations: Clientele effects and legal liability. Journal of Accounting and Economics 29(2), 173-205.

Ziedonis, R. H. (2004). Don't fence me in: Fragmented markets for technology and the patent acquisition strategies of firms. Management Science 50(6), 804-820. 


\section{Table I. Summary Statistics, 2001 - 2011}

Appendix Table A1 contains the definitions of the variables we use. Panel A of this table presents summary statistics on the firms included in the tests. Panel B tabulates the number of firms by incidence of being subject to a litigation filed by an NPE.

Panel A. Summary Statistics on Firm Characteristics

\begin{tabular}{rrrrrrrr}
\hline & Mean & Median & St. dev & P05 & P25 & P75 & P95 \\
\hline Market Value & 4050.06 & 338.44 & 17294.53 & 13.21 & 76.76 & 1491.83 & 16468.02 \\
Total Assets & 10.39 & 0.52 & 83.90 & 0.02 & 0.11 & 2.23 & 25.27 \\
Book to Market & 0.70 & 0.55 & 0.65 & 0.12 & 0.32 & 0.86 & 1.72 \\
Past Return & 0.13 & 0.05 & 0.63 & -0.70 & -0.22 & 0.34 & 1.20 \\
Number of Law Firms & 0.66 & 0.00 & 4.81 & 0.00 & 0.00 & 0.00 & 2.00 \\
Cash Shock & 0.04 & 0.00 & 0.19 & 0.00 & 0.00 & 0.00 & 0.00 \\
Patent Stock & 11.86 & 0.00 & 112.23 & 0.00 & 0.00 & 0.00 & 22.00 \\
In-house Counsel & 0.03 & 0.00 & 0.17 & 0.00 & 0.00 & 0.00 & 0.00 \\
Ongoing Cases & 0.18 & 0.00 & 0.39 & 0.00 & 0.00 & 0.00 & 1.00 \\
Cash Level & 0.31 & 0.02 & 1.83 & 0.00 & 0.01 & 0.09 & 1.00 \\
\hline
\end{tabular}

Panel B. Number of Firms Sued by Non-practicing Entities (NPEs)

\begin{tabular}{rrr}
\hline Year & Sued by NPE & Total Firms \\
\hline 2001 & 11 & 5,607 \\
2002 & 43 & 5,375 \\
2003 & 48 & 5,402 \\
2004 & 70 & 5,067 \\
2005 & 85 & 4,959 \\
2006 & 142 & 4,761 \\
2007 & 235 & 4,709 \\
2008 & 186 & 4,548 \\
2009 & 230 & 4,412 \\
2010 & 328 & 4,356 \\
2011 & 336 & 4,231 \\
Total & 1,714 & 53,427 \\
\hline
\end{tabular}




\section{Table II. Cash and Probability of Being Sued}

In this table, we use OLS regression to estimate the probability of being sued by an NPE. The outcome variable, Sued by NPE, is a dummy equal to 1 if the firm was litigated by an NPE that year. Total Assets of the firm are as of the end of the previous fiscal year. Market Value of the equity is measured as of the end of the previous fiscal year. Book-to-market ratio $(B / M)$ is the ratio of book value of equity to market value of equity as of the end of the previous fiscal year. Book value of equity is calculated as sum of stockholders equity (SEQ), Deferred Tax (TXDB), and Investment Tax Credit (ITCB), minus Preferred Stock (PREF). Past Return is the 12-month return prior to fiscal year end. Patent Stock is the number of patents the firm applied for in the past five years. Cash Level is the amount of cash reported on the balance sheet as of the beginning of the previous fiscal year. Cash Shock is a dummy variable equal to 1 if the change in cash in the current fiscal year compared to that of the previous fiscal year is among the top 90 percentile of cash changes. We use log transformation for Total Assets, Market Value, B/M, Patent Stock, and Cash Level. The sample contains firm-year observations between 2001 and 2011. Standard errors, clustered by firm, are reported in parentheses. ${ }^{* * *}, * *$, and $*$ denote statistical significance at the 1,5 , and 10 percent levels.

\begin{tabular}{|c|c|c|c|c|c|}
\hline & Sued by NPE & Sued by NPE & Sued by NPE & Sued by NPE & Sued by NPE \\
\hline Total Assets & $\begin{array}{r}0.0001^{* *} \\
(0.000)\end{array}$ & $\begin{array}{r}0.0002^{* *} \\
(0.000)\end{array}$ & $\begin{array}{r}0.0001^{*} \\
(0.000)\end{array}$ & $\begin{array}{r}0.0002^{* *} \\
(0.000)\end{array}$ & $\begin{array}{r}0.0001 \\
(0.000)\end{array}$ \\
\hline Market Value & $\begin{array}{r}0.0131^{* * *} \\
(0.001)\end{array}$ & $\begin{array}{r}-0.0014 \\
(0.002)\end{array}$ & $\begin{array}{r}-0.0046^{* *} \\
(0.002)\end{array}$ & $\begin{array}{r}-0.0016 \\
(0.002)\end{array}$ & $\begin{array}{r}-0.0049^{* *} \\
(0.002)\end{array}$ \\
\hline $\mathrm{B} / \mathrm{M}$ & $\begin{array}{r}0.0167^{* * * *} \\
(0.004)\end{array}$ & $\begin{array}{r}0.0246^{* * *} \\
(0.006)\end{array}$ & $\begin{array}{r}0.0160^{* * *} \\
(0.006)\end{array}$ & $\begin{array}{r}0.0246^{* * *} \\
(0.006)\end{array}$ & $\begin{array}{r}0.0159^{* * *} * \\
(0.006)\end{array}$ \\
\hline Past Return & $\begin{array}{r}0.0023^{* *} \\
(0.001)\end{array}$ & $\begin{array}{r}-0.0008 \\
(0.001)\end{array}$ & $\begin{array}{r}-0.0011 \\
(0.001)\end{array}$ & $\begin{array}{r}-0.0009 \\
(0.001)\end{array}$ & $\begin{array}{r}-0.0012 \\
(0.001)\end{array}$ \\
\hline Patent Stock & $\begin{array}{r}0.0131^{* * *} \\
(0.002)\end{array}$ & $\begin{array}{r}0.0075^{* * *} * \\
(0.003)\end{array}$ & $\begin{array}{r}0.0065^{* * *} \\
(0.002)\end{array}$ & $\begin{array}{r}0.0075^{* * *} \\
(0.003)\end{array}$ & $\begin{array}{r}0.0064^{* * *} \\
(0.002)\end{array}$ \\
\hline Cash Level & & & $\begin{array}{r}0.1046^{* * *} \\
(0.015)\end{array}$ & & $\begin{array}{r}0.1063^{* * *} \\
(0.016)\end{array}$ \\
\hline Cash Shock & & & & $\begin{array}{r}0.0167^{* *} \\
(0.008)\end{array}$ & $\begin{array}{r}0.0213^{* *} \\
(0.008)\end{array}$ \\
\hline Firm FE & No & Yes & Yes & Yes & Yes \\
\hline Year FE & Yes & Yes & Yes & Yes & Yes \\
\hline $\mathrm{N}$ & 53,420 & 53,420 & 53,420 & 53,420 & 53,420 \\
\hline $\mathrm{R} 2$ & 0.07 & 0.42 & 0.42 & 0.42 & 0.42 \\
\hline
\end{tabular}




\section{Table III. Probability of Being Sued and Ex-ante Loss Likelihood}

In this table, we use OLS regression to estimate the probability of being sued by an NPE. The outcome variable, Sued by NPE, is a dummy equal to 1 if the firm was litigated by an NPE that year. Total Assets of the firm are as of the end of the previous fiscal year. Market Value of the equity is measured as of the end of the previous fiscal year. Book-to-market ratio (B/M) is the ratio of book value of equity to market value of equity as of the end of the previous fiscal year. Book value of equity is calculated as sum of stockholders equity (SEQ), Deferred Tax (TXDB), and Investment Tax Credit (ITCB), minus Preferred Stock (PREF). Past Return is the 12-month return prior to fiscal year end. Patent Stock is the number of patents the firm applied for in the past five years. Cash Level is the amount of cash reported on the balance sheet as of the beginning of the previous fiscal year. Cash Shock is a dummy variable equal to 1 if the change in cash in the current fiscal year compared to that of the previous fiscal year is among the top 90 percentile of cash changes. Excess Lawyers is the residual number of lawyers left after deducting the model-estimated number of lawyers (Appendix Table A2) from the actual number of lawyers with whom the firm works. Ongoing Cases equals 1 if the firm was engaged in non-IP-related litigation that year. We use log transformation for Total Assets, Market Value, B/M, Patent Stock, and Cash Level. The sample contains firm-year observations between 2001 and 2011. Standard errors, clustered by firm, are reported in parentheses. ${ }^{* * *},{ }^{* *}$, and ${ }^{*}$ denote statistical significance at the 1,5 , and 10 percent levels.

\begin{tabular}{rrrrr}
\hline & Sued by NPE & Sued by NPE & Sued by NPE & Sued by NPE \\
\hline Total Assets & 0.0001 & $0.0002^{*}$ & 0.0001 & $0.0002^{*}$ \\
& $(0.000)$ & $(0.000)$ & $(0.000)$ & $(0.000)$ \\
Market Value & $-0.0049^{* *}$ & $-0.0046^{* *}$ & $-0.0053^{* *}$ & $-0.0051^{* *}$ \\
& $(0.002)$ & $(0.002)$ & $(0.002)$ & $(0.002)$ \\
$\mathrm{B} / \mathrm{M}$ & $0.0159^{* * *}$ & $0.0163^{* * *}$ & $0.0145^{* *}$ & $0.0149^{* *}$ \\
& $(0.006)$ & $(0.006)$ & $(0.006)$ & $(0.006)$ \\
Past Return & -0.0012 & -0.0012 & -0.0012 & -0.0012 \\
& $(0.001)$ & $(0.001)$ & $(0.001)$ & $(0.001)$ \\
Number of Patents & $0.0064^{* * *}$ & $0.0063^{* * *}$ & $0.0064^{* * *}$ & $0.0062^{* * *}$ \\
& $(0.002)$ & $(0.002)$ & $(0.002)$ & $(0.002)$ \\
Cash Level & $0.1063^{* * *}$ & $0.1069^{* * *}$ & $0.1052^{* * *}$ & $0.1058^{* * *}$ \\
& $(0.016)$ & $(0.015)$ & $(0.016)$ & $(0.015)$ \\
Cash Shock & $0.0213^{* *}$ & $0.0216^{* * *}$ & $0.0214^{* *}$ & $0.0217^{* * *}$ \\
& $(0.008)$ & $(0.008)$ & $(0.008)$ & $(0.008)$ \\
Excess Lawyers & & $-0.1295^{* *}$ & & $-0.1309^{* *}$ \\
& & $(0.056)$ & & $(0.056)$ \\
Ongoing Cases & & & $0.0167^{* * *}$ & $0.0169^{* * *}$ \\
& & & $(0.006)$ & $(0.006)$ \\
Firm FE & Yes & Yes & Yes & Yes \\
Year FE & Yes & Yes & Yes & Yes \\
$\mathrm{N}$ & 53,420 & 53,420 & 53,420 & 53,420 \\
$\mathrm{R} 2$ & 0.42 & 0.42 & 0.42 & 0.42 \\
\hline
\end{tabular}




\section{Table IV. Total Profitability and Being Sued by NPEs}

This table reports a split-sample analysis using two dummies, Litigation and Ongoing Cases. The outcome variable, Sued by NPE, equals 1 if the firm was litigated by an NPE that year. The legend of Table III discusses the independent variables. The sample contains firm-year observations between 2001 and 2011. Standard errors, clustered by firm, are reported in parentheses. ***, **, and ${ }^{*}$ denote statistical significance at the 1,5 , and 10 percent levels.

\begin{tabular}{|c|c|c|c|c|}
\hline & Sued by NPE & Sued by NPE & Sued by NPE & Sued by NPE \\
\hline \multirow[t]{2}{*}{ Total Assets } & $0.0002^{*}$ & 0.0001 & 0.0001 & 0.0001 \\
\hline & $(0.000)$ & $(0.000)$ & $(0.000)$ & $(0.000)$ \\
\hline \multirow[t]{2}{*}{ Market Value } & $-0.0058^{* * *}$ & $-0.0054^{* *}$ & $-0.0040^{*}$ & $-0.0052^{* *}$ \\
\hline & $(0.002)$ & $(0.002)$ & $(0.002)$ & $(0.002)$ \\
\hline \multirow[t]{2}{*}{$\mathrm{B} / \mathrm{M}$} & $0.0138^{* *}$ & $0.0145^{* *}$ & $0.0161 * * *$ & $0.0146^{* *}$ \\
\hline & $(0.006)$ & $(0.006)$ & $(0.006)$ & $(0.006)$ \\
\hline \multirow[t]{2}{*}{ Past Return } & -0.0012 & -0.0012 & -0.001 & -0.0011 \\
\hline & $(0.001)$ & $(0.001)$ & $(0.001)$ & $(0.001)$ \\
\hline \multirow[t]{2}{*}{ Number of Patents } & $0.0064^{* * *}$ & $0.0064^{* * *}$ & $0.0062 * * *$ & $0.0064^{* * *}$ \\
\hline & $(0.002)$ & $(0.002)$ & $(0.002)$ & $(0.002)$ \\
\hline \multirow[t]{2}{*}{ Cash Level } & $0.1190 * * *$ & $0.1055^{* * *}$ & $0.0421^{* *}$ & $0.1045^{* * *}$ \\
\hline & $(0.016)$ & $(0.016)$ & $(0.018)$ & $(0.016)$ \\
\hline \multirow[t]{2}{*}{ Cash Shock } & $0.0213^{* *}$ & $0.0249 * * *$ & $0.0223^{* * *}$ & 0.0041 \\
\hline & $(0.008)$ & $(0.010)$ & $(0.008)$ & $(0.010)$ \\
\hline \multirow[t]{2}{*}{ Excess Lawyers } & 0.0098 & 0 & -0.001 & -0.0011 \\
\hline & $(0.008)$ & $(0.007)$ & $(0.007)$ & $(0.007)$ \\
\hline \multirow[t]{2}{*}{ Ongoing Cases } & $0.0167 * * *$ & $0.0167 * * *$ & -0.002 & $0.0151^{* * *}$ \\
\hline & $(0.006)$ & $(0.006)$ & $(0.006)$ & $(0.006)$ \\
\hline Cash Level x Excess Lawyers & $\begin{array}{r}-0.0267^{* *} * \\
(0.011)\end{array}$ & & & \\
\hline Cash Shock x Excess Lawyers & & $\begin{array}{r}-0.0086 \\
(0.016)\end{array}$ & & \\
\hline Cash Level x Ongoing Cases & & & $\begin{array}{r}0.1086^{* * *} \\
(0.024)\end{array}$ & \\
\hline Cash Shock x Ongoing Cases & & & & $\begin{array}{r}0.0352^{* *} \\
(0.018)\end{array}$ \\
\hline Firm FE & Yes & Yes & Yes & Yes \\
\hline Year FE & Yes & Yes & Yes & Yes \\
\hline $\mathrm{N}$ & 53,420 & 53,420 & 53,420 & 53,420 \\
\hline $\mathrm{R} 2$ & 0.42 & 0.42 & 0.42 & 0.42 \\
\hline
\end{tabular}




\section{Table V. Probability of Being Sued: Related vs. Unrelated Cash Flows}

In this table, we report the probability of a conglomerate being sued by an NPE as a function of the gross profitability of related and unrelated segments. The unit of observation is a conglomeratesegment-year. Sued by NPE is a dummy variable equal to 1 if the firm was litigated by an NPE that year. To identify segments that are related to litigated patents, we use the IPC-to-SIC concordance developed by Silverman (2002). We use financial statements disclosed in segment filings to collect segment-level information on sales and cost of goods sold and calculate segment profitability as the difference. Industry Profitability is the average profitability of all firms in the same four-digit SIC. Our sample includes all conglomerates, between 2001 and 2011, which had more than one segment reporting profitability data. Standard errors, clustered by firm, are reported in parentheses. ***, **, and ${ }^{*}$ denote statistical significance at the 1,5 , and 10 percent levels.

\begin{tabular}{rrr}
\hline & Segment sued by NPE & Segment sued by NPE \\
\hline Related Segment Profitability & $0.0110^{* *}$ & $0.0065^{* * *}$ \\
& $(0.005)$ & $(0.002)$ \\
Unrelated Segment Profitability & $0.0110^{* * *}$ & $0.0051^{* * *}$ \\
& $(0.003)$ & $(0.002)$ \\
Industry Profitability & $-0.0004^{* * *}$ & 0.0001 \\
& $(0.000)$ & $(0.000)$ \\
Conglomerate FE & No & Yes \\
& & 29,756 \\
$\mathrm{~N}$ & 0.02 & 0.37 \\
$\mathrm{R} 2$ & &
\end{tabular}




\section{Table VI. Probability of Being Sued by a Practicing Entity (PE)}

The outcome variable in this table, Sued by PE, is a dummy equal to 1 if the firm was litigated by a PE that year. All independent variables are identical to those used and described in Table III. The sample contains firm-year observations between 2001 and 2011. Standard errors, clustered by firm, are reported in parentheses. $* * *, * *$, and $*$ denote statistical significance at the 1,5 , and 10 percent levels.

\begin{tabular}{rrrrr}
\hline & Sued by PE & Sued by PE & Sued by PE & Sued by PE \\
\hline Total Assets & 0.0001 & 0.0001 & 0.0001 & 0.0001 \\
& $(0.000)$ & $(0.000)$ & $(0.000)$ & $(0.000)$ \\
Market Value & 0.002 & 0.0019 & 0.0023 & 0.0022 \\
& $(0.002)$ & $(0.002)$ & $(0.002)$ & $(0.002)$ \\
B/M & 0.0009 & 0.0007 & 0.0017 & 0.0015 \\
& $(0.006)$ & $(0.006)$ & $(0.006)$ & $(0.006)$ \\
Past Return & -0.0015 & -0.0015 & -0.0016 & -0.0016 \\
& $(0.001)$ & $(0.001)$ & $(0.001)$ & $(0.001)$ \\
Number of Patents & 0.0011 & 0.0012 & 0.0011 & 0.0012 \\
& $(0.002)$ & $(0.002)$ & $(0.002)$ & $(0.002)$ \\
Cash Level & $-0.0213^{* *}$ & $-0.0216^{* *}$ & $-0.0207^{* *}$ & $-0.0210^{* *}$ \\
& $(0.010)$ & $(0.010)$ & $(0.010)$ & $(0.010)$ \\
Cash Shock & 0.0071 & 0.0069 & 0.007 & 0.0069 \\
& $(0.007)$ & $(0.007)$ & $(0.007)$ & $(0.007)$ \\
Excess Lawyers & & 0.059 & & 0.0598 \\
& & $(0.041)$ & & $(0.041)$ \\
Ongoing Cases & & & $-0.0093^{* *}$ & $-0.0094^{* *}$ \\
& & & $(0.004)$ & $(0.004)$ \\
Firm FE & Yes & Yes & Yes & Yes \\
Year FE & Yes & Yes & Yes & Yes \\
$\mathrm{N}$ & 53,420 & 53,420 & 53,420 & 53,420 \\
$\mathrm{R} 2$ & 0.28 & 0.28 & 0.28 & 0.28 \\
\hline
\end{tabular}




\section{Table VII. Real Outcomes}

Panel A reports the probit estimates of a treatment effects model to compare the number of RD Expense, patent applications and the number of citations to those patents for two categories of firms that have been targeted by NPEs: (1) firms that are litigated but get the case dismissed and (2) firms that are litigated and lose the litigation. Panel B reports the difference between new patent applications (or citations to those patents), RD Expense (All), and RD Expense (Acquired) one year before the litigation and one year after it. Panel $\mathrm{C}$ reports the difference in new citations to patent portfolios that were patented before the litigation. Standard errors, clustered by firm, are reported in parentheses. ${ }^{* * *}, * *$, and ${ }^{*}$ denote statistical significance at the 1,5 , and 10 percent levels.

Panel A. Probit (Dismissed vs. Lost by the Firm)

\begin{tabular}{rr}
\hline & $\mathrm{P}($ Dismissed $)$ \\
\hline & $\mathrm{P}($ Dismissed) \\
Total Assets & $0.0013^{* * *}$ \\
& $(0.000)$ \\
Market Value & -0.0323 \\
& $(0.081)$ \\
B/M & -0.1984 \\
& $(0.491)$ \\
Past Return & -0.1136 \\
& $(0.194)$ \\
Patents Stock & 0.0121 \\
& $(0.029)$ \\
Cash Level & -0.2377 \\
& $(0.199)$ \\
Cash Shock & $0.4796^{* *}$ \\
& $(0.219)$ \\
Excess Lawyers & -0.6314 \\
& $(1.117)$ \\
Other Cases & 0.3219 \\
& $(0.203)$ \\
Year FE & Included \\
& 484 \\
$\mathrm{~N}$ & 0.086 \\
$\mathrm{R} 2$ &
\end{tabular}

Panel B. Treatment Effects Model

\begin{tabular}{rrrr}
\hline & Sample Comparison & Difference & z-stat \\
\hline & Sample Comparison & Difference & z-stat \\
R\&D Expense (All) & Dismissed vs. Settled/ NPE Won & $211.03^{* *}$ & 1.96 \\
R\&D Expense (Acquired) & Dismissed vs. Settled/ NPE Won & $49.28^{* * *}$ & 2.95 \\
New Patents & Dismissed vs. Settled/ NPE Won & $63.65^{* * *}$ & 2.96 \\
Total Citations & Dismissed vs. Settled/ NPE Won & $723.98^{* * *}$ & 3.45 \\
\hline
\end{tabular}

Panel C. Placebo Test

\begin{tabular}{lrrr}
\hline & Sample Comparison & Difference & z-stat \\
\hline Citations per patent for patents created before the litigation & Dismissed vs. Settled/ NPE Won & 0.35 & 1.21 \\
\hline
\end{tabular}




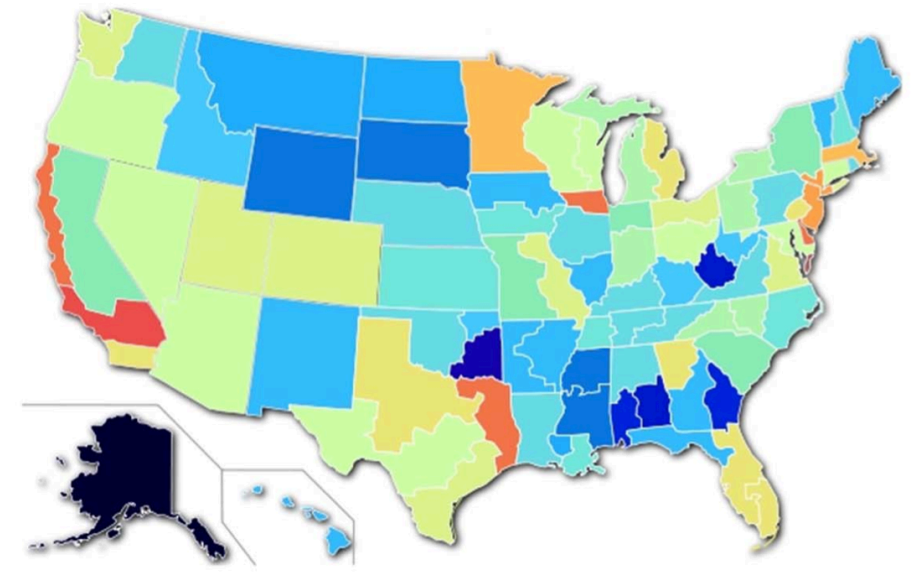

Legend

LEAST CASES

MOST CASES

Figure 1. This figure provides a heatmap of IP Litigation by state 


\section{Appendix - Patent Trolls: Evidence from Targeted Firms}




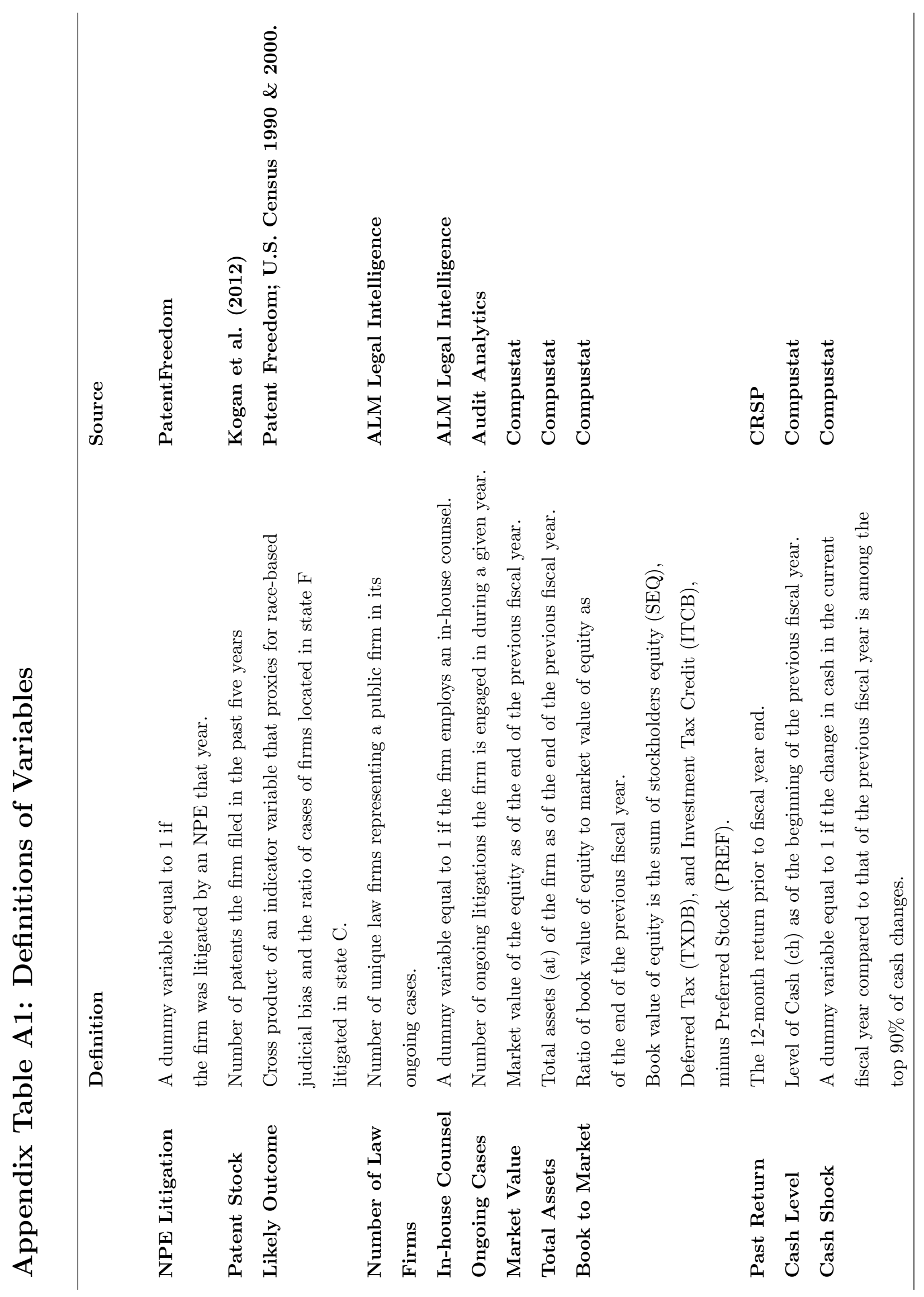




\section{Appendix Table A2: Measures of Likely Outcome and Excess Lawyers}

In Panel A, we measure the number of excess lawyers based on a model that predicts the number of lawyers used by comparable firms. We regress log number of lawyers on (a) how much intellectual property the firm possesses $(\log ($ Patent Stock) $)$, (b) whether the firm has an in-house counsel (Inhouse Counsel), a department of lawyers housed inside the firm to handle its most frequent legal issues, (c) the most recent market performance of the firm's equity, and (d) firm fixed effects. In Panel B, we regress the outcome of patent litigation on our Likely Outcome proxy. The outcome variable equals 1 if the case ended in favor of NPE or was settled out of court. The Likely Outcome proxy combines two pieces of information. The first piece is the probability of being sued in state $C$ if a firm from industry $J$ is located in state $F$. To calculate this probability, we use the ratio of the number of firms in industry $J$ in state $F$ sued in state $C$ to the number of firms in industry $J$ in state $F$ sued in all states prior to time $t$. The second piece of information is the ex ante probability of an NPE winning the case due to an ethnicity bias in the juror pool. We capture the judicial bias by an indicator variable that compares Asian ethnicity in state $F$ and state $C$. Thus, our litigation proxy takes the following form:

$$
\text { Likely } \operatorname{Outcome}(j, f, t)=\left(\sum_{C \neq F} \frac{n(j, C, t-1)}{\sum_{C^{\prime}} n\left(j, C^{\prime}, t-1\right)}\right) \cdot \mathbf{1}(\operatorname{Asian}(C)<\operatorname{Asian}(F)) .
$$

Using this Likely Outcome proxy, we use OLS to report its correlation with favorable case outcomes for NPEs.

Panel A. Estimating the Number of Excess Lawyers

\begin{tabular}{|c|c|c|c|c|c|}
\hline & Log (\# of Lawyers) & Log (\# of Lawyers) & Log (\# of Lawyers) & Log (\# of Lawyers) & Log (\# of Lawyers) \\
\hline Patent Stock & & $\begin{array}{r}0.0989 * * * \\
(0.006)\end{array}$ & & & $\begin{array}{r}0.0640 * * * \\
(0.004)\end{array}$ \\
\hline In-house Counsel & & & $\begin{array}{r}1.9238^{* * *} \\
(0.039)\end{array}$ & & $\begin{array}{r}1.8283^{* * *} \\
(0.036)\end{array}$ \\
\hline Past Return & & & & $\begin{array}{r}-0.0044^{* * *} \\
(0.001)\end{array}$ & $\begin{array}{r}-0.0049 * * * \\
(0.001)\end{array}$ \\
\hline Year FE & Yes & Yes & Yes & Yes & Yes \\
\hline Firm FE & Yes & Yes & Yes & Yes & Yes \\
\hline $\mathrm{N}$ & 82,540 & 82,540 & 82,540 & 82,540 & 82,540 \\
\hline $\mathrm{R} 2$ & 0.03 & 0.11 & 0.4 & 0.03 & 0.44 \\
\hline
\end{tabular}

Panel B. Validation of Likely Outcome Proxy

\begin{tabular}{rrrr}
\hline & In favor of NPE & In favor of NPE & In favor of NPE \\
\hline Likely Outcome & & $0.0964^{* *}$ & $0.1275^{*}$ \\
& & $(0.049)$ & $(0.067)$ \\
Year FE & Yes & Yes & Yes \\
State FE & Yes & Yes & No \\
Industry FE & Yes & Yes & No \\
Firm FE & No & No & Yes \\
& & & 17,368 \\
$\mathrm{~N}$ & 17,368 & 17,368 & 0.22 \\
$\mathrm{R} 2$ & 0.16 & 0.17 &
\end{tabular}




\section{Appendix Table A3: Probability of Being Sued and Likely Outcome Measure}

In this table, we run an analysis identical to that in Table IV, with all variables and regression specification detailed there. The additional variables of interest are Likely Outcome, described in Appendix Table A2, and the interactions of Likely Outcome with Cash Level and Cash Shock.

\begin{tabular}{rrr}
\hline & Sued by NPE & Sued by NPE \\
\hline Total Assets & 0.0001 & 0.0001 \\
& $(0.000)$ & $(0.000)$ \\
Market Value & $-0.0052^{* *}$ & $-0.0054^{* *}$ \\
& $(0.002)$ & $(0.002)$ \\
B/M & $0.0145^{* *}$ & $0.0144^{* *}$ \\
& $(0.006)$ & $(0.006)$ \\
Past Return & -0.0011 & -0.0012 \\
& $(0.001)$ & $(0.001)$ \\
Number of Patents & $0.0064^{* * *}$ & $0.0063^{* * *}$ \\
& $(0.002)$ & $(0.002)$ \\
Cash Level & $0.0816^{* * *}$ & $0.1048^{* * *}$ \\
& $(0.016)$ & $(0.015)$ \\
Cash Shock & $0.0219^{* * *}$ & 0.0055 \\
& $(0.008)$ & $(0.009)$ \\
Excess Lawyers & 0.0003 & -0.0005 \\
& $(0.007)$ & $(0.007)$ \\
Likely Outcome & $-0.0057^{*}$ & 0.0007 \\
& $(0.003)$ & $(0.003)$ \\
Ongoing Cases & $0.0166^{* * *}$ & $0.0167^{* * *}$ \\
& $(0.006)$ & $(0.006)$ \\
Cash Level x Likely Outcome & $0.0645^{* * *}$ & \\
& $(0.023)$ & \\
Cash Shock x Likely Outcome & & $0.0485^{* *}$ \\
& & $(0.019)$ \\
R2 & Yes & Yes \\
Year FE & Yes & Yes \\
& 53,420 & 53,420 \\
& 0.42 & 0.42 \\
\hline & &
\end{tabular}


Appendix Table A4: Number of Firms Sued by Non-practicing Entities (NPEs) vs. Practicing Entities (PEs), 2001-2011

\begin{tabular}{rrrr}
\hline Year & Sued by NPE & Sued by PE & Total Firms \\
\hline 2001 & 11 & 142 & 5,606 \\
2002 & 43 & 95 & 5,373 \\
2003 & 48 & 148 & 5,401 \\
2004 & 70 & 152 & 5,066 \\
2005 & 85 & 141 & 4,959 \\
2006 & 142 & 153 & 4,760 \\
2007 & 235 & 177 & 4,709 \\
2008 & 186 & 112 & 4,547 \\
2009 & 230 & 122 & 4,412 \\
2010 & 328 & 133 & 4,356 \\
2011 & 336 & 156 & 4,231 \\
Total & 1,714 & 1,531 & 53,420 \\
\hline
\end{tabular}

